\title{
Growth of Eucalyptus urocam Under Different Irrigation Managements
}

\author{
L. R. De Oliveira ${ }^{1}$, A. R. B. Marques ${ }^{1}$, D. Da Silva ${ }^{1}$, W. B. Sidião ${ }^{1}$, W. S. Dos Santos¹, V. A. Amorim¹, \\ L. P. Borges ${ }^{1} \&$ F. S. Matos ${ }^{1}$ \\ ${ }^{1}$ Research Group on Physiology of Vegetable Production, State University of Goiás, Ipameri, Brazil \\ Correspondence: F. S. Matos, Research Group on Physiology of Vegetable Production, State University of Goiás, \\ Highway GO 330 km 241, Ring Road, Zip Code 75780-000, Ipameri, Brazil. E-mail: \\ fabio.agronomia@hotmail.com
}

$\begin{aligned} & \text { Received: December 31, } 2018 \\ & \text { Accepted: February 1, } 2019 \quad \text { Online Published: March 15, } 2019 \\ & \text { doi:10.5539/jas.v11n4p92 }\end{aligned}$ URL: https://doi.org/10.5539/jas.v11n4p92

\begin{abstract}
The objective of the present study was to evaluate the effects of different water irrigation managements on the growth of Eucalyptus urocam plants. The experiment was conducted in a greenhouse at the Goiás State University, Ipameri campus, Brazil, using 100-day-old Eucalyptus urocam seedlings, which were transplanted into pots with $5 \mathrm{~kg}$ of substrate. A completely randomized experimental design with five replications was used, in a $2 \times 4$ factorial arrangement consisting of two daily irrigation depths $(50 \%$, and $100 \%$ of the substrate retention capacity) and four irrigation times (7:30 a.m., 11:30 a.m., 4:30 p.m., and 7:00 p.m.). The treatments were applied when the plants were 120 days old, and last 18 days, then, the variables were analyzed. E. urocam plants subjected to water deficit had high stomatal sensitivity, reduced transpiration rate, and maintained hydration, which are characteristics of isohydric plants. E. urocam plants irrigated at 4:30 p.m. or 7:00 p.m. presented low stomatal sensitivity and high biomass accumulation potential. Therefore, irrigations between 4:30 p.m. and 7:00 p.m. are recommended for Eucalyptus urocam plants at the initial growth stage.
\end{abstract}

Keywords: forestry, stomatal sensitivity, water supply

\section{Introduction}

Areas with forest plantations are increasing worldwide. Restoration of degraded landscapes, conservation of native tree species, wood and cellulose supply, and carbon sequestration are the main reasons for growing forest species (Pozo \& Säumel, 2018). In the last decades, plantations have increased from 1675 Mha in 1990 to 2779 Mha in 2015, equivalent to 7\% of global forest cover (Payn et al., 2015).

Despite the diversity of tree species, Eucalyptus spp. dominate planted forests worldwide and is used in intensive management systems due to its easy establishment, high short-term productivity, and good adaptation to different climatic conditions (Binkley et al., 2017). The world area with eucalyptus crops exceeds 20 million hectares; India accounts for $22 \%$, Brazil $20 \%$, and China $14 \%$ of the global production (GIT Forestry, 2008). Most eucalyptus plantations are grown to supply wood for cellulose and timber markets, moreover, interest on other products such as solid wood, laminate wood, charcoal, and biomass, has been growing (Jesus et al., 2017).

Despite the success of planted forests, the sector can grow even more with the use of areas that are unsuitable for many other crops that are less tolerant to abiotic stresses (Lopes et al., 2015). Decreases in available agricultural areas led eucalyptus crops to marginal regions that have low-fertility soils and low water availability (Acuña, Rubilar, Cancino, Albaugh, \& Maier, 2018).

Water deficit is the greatest obstacle to increase agricultural productivity. It is one of the most critical abiotic stresses and the one that most limit the growth of eucalyptus plants (Matos et al., 2016). Climate change has intensified drought periods in several regions of the world, increasing problems commonly faced by producers (Schlaepfer et al., 2017). Water deficit significantly hinders biomass accumulation by eucalyptus plants. Changes in water and thermal regimes reduce the plant's metabolic capacity and change their gas and water exchange activity, with significant damage to wood formation and anatomy (Sette Junior, Tomazello Filho, Lousada, \& Laclau, 2010).

Water deficit symptoms in eucalyptus plants at the initial stage of development are more severe and visible, affecting plant growth and increasing plant mortality in the field (Cabral et al., 2010). According to Valdés et al. 
(2013), multiple responses are activated when trees are under water deficit to synchronize their development with molecular activities and guarantee their survival. Plants subjected to water deficit activate morphological, physiological, or anatomical mechanisms to adapt to drought (Tatagiba, Pezzopane, Dos Reis, \& Penchel, 2009). Identifying these mechanisms may explain the resistance to drought of eucalyptus plants.

Evaluating irrigation water depths in different times of the day may assist in avoiding losses caused by water deficit. The irrigation of cultivated plants represents one of the most important advances to obtain high biomass yields, as the water supply in sufficient volumes increases the growth of the plants. Over the years many irrigation systems have been developed and the studies have advanced markedly with determination of the appropriate method of irrigation and volume of water to be applied under various environmental conditions, however, the recommendation of the appropriate irrigation schedule still lacks further scientific investigation.

It has been believed since the $14^{\text {th }}$ century that one should not water plants under full sun (Power, 1928), but evidences with scientific basis are needed for such claim. However, few studies show the effects of irrigation in different times of the day on plant growth. In this context, the objective of the present study was to evaluate the effects of different water irrigation managements on the growth of Eucalyptus urocam plants.

\section{Material and Methods}

The experiment was conducted in a greenhouse covered with a transparent plastic at the Goiás State University, Ipameri campus, Brazil $\left(17^{\circ} 43^{\prime} 19^{\prime \prime} \mathrm{S}, 48^{\circ} 09^{\prime} 35^{\prime \prime} \mathrm{W}\right.$, and altitude of $\left.764 \mathrm{~m}\right)$. The climate of the region is tropical, with dry winter and wet summer (Aw), according to the Köppen classification, with average temperature of $20^{\circ} \mathrm{C}$ (Alvares Stape, Sentelhas, Gonçalves, \& Sparovek, 2013).

Eucalyptus urocam seedlings of 100 days old from a seedling production nursery were transplanted to pots with $5 \mathrm{~kg}$ of a substrate consisted of Oxisol, sand, and manure (3:1:0.5). Based on the chemical analysis of the substrate: $\mathrm{pH}$ of $6.4,19 \mathrm{~g} \mathrm{dm}^{-3}$ of organic matter, $2.4 \mathrm{mg} \mathrm{dm}^{-3}$ of $\mathrm{P}, 109 \mathrm{cmol}_{\mathrm{c}} \mathrm{dm}^{-3}$ of K, $1.5 \mathrm{cmol}_{\mathrm{c}} \mathrm{dm}^{-3}$ of $\mathrm{H}+\mathrm{Al}$, $3.2 \mathrm{cmol}_{\mathrm{c}} \mathrm{dm}^{-3}$ of $\mathrm{Ca}, 1.6 \mathrm{cmol}_{\mathrm{c}} \mathrm{dm}^{-3}$ of $\mathrm{Mg}, 27.7 \mathrm{mg} \mathrm{dm}^{-3}$ of $\mathrm{Zn}$, base saturation of $77.20 \%$, and cation exchange capacity of 6.58 - no liming or fertilization were performed.

The experiment was conducted in a completely randomized design with five replications, using a $2 \times 4$ factorial arrangement consisted of two daily irrigation depths $(50 \%$, and $100 \%$ of the substrate retention capacity) and four irrigation times (7:30 a.m., 11:30 a.m., 4:30 p.m., and 7:00 p.m.). The water retention capacity of the substrate was determined by the difference in weight of the pots as described by Sá et al. (2017). The irrigation was done manually with application of pre-determined volume of water using graduated container. The treatments were applied when the plants were 120 days old, and the experiment last 18 days, then, the following variables were analyzed: plant height, stem diameter, relative water content, number of leaves, transpiration rate, total plant weight, root weight ratio, stem weight ratio, shoot weight ratio, specific leaf area, and leaf chlorophyll content.

\subsection{Variables}

Plant height and stem diameter were measured using a graded ruler and digital pachimeter, respectively. The number of leaves was measured by counting all the leaves on each plant.

For destructive testing, the roots, stems and leaves were separated and dried in an oven at $72{ }^{\circ} \mathrm{C}$ until constant dry weight and then weighed. The dry weight data were used to calculate the root mass ratio (RMR), stem mass ratio (SMR), leaf mass ratio (LMR) and total biomass. To obtain the specific leaf area (SLA), six leaf discs of 12 $\mathrm{mm}$ in diameter were removed from the leaves in a drying oven and SLA was then determined by dividing the area of the six discs by the dry mass of the discs.

Total daily plant transpiration was determined by the difference in weight of the pots. First, each pot was placed inside a plastic bag attached to the stem of the plant with a rubber band, leaving only the aerial parts (stem and leaves) exposed. Next, the pot (and bag) was weighed at $12 \mathrm{pm}$ (weight 1 ) and then again 24 hours later (weight 2). Total transpiration was estimated based on the difference between weight 1 and 2 (Dos Anjos et al., 2017). In order to calculate relative water content, ten $14 \mathrm{~mm}$-wide leaf discs were collected, weighed and immersed in distilled water for $8 \mathrm{~h}$ in Petri dishes. Next, the discs were weighed and dried at $70{ }^{\circ} \mathrm{C}$ for 72 hours.

To determine the chlorophyll concentration, leaf disks were removed from the known area and placed in jars containing dimethyl sulfoxide (DMSO). Later extraction was carried out in a water bath at $65^{\circ} \mathrm{C}$ for one hour. Aliquots were removed for spectrophotometric reading at 480, 646 and $665 \mathrm{~nm}$. The chlorophyll a $(\mathrm{Cl} a)$ and chlorophyll $\mathrm{b}(\mathrm{Cl} b)$ contents were determined following the equation proposed by Wellburn (1994).

The work was set up in a completely randomized design in a 24 factorial with five replicates. The data was 
submitted to analysis of variance and the Tukey test to compare the means. Multivariate analysis was carried out by multiple regression using the forward stepwise model (Sokal \& Rolf, 1995) and Principal component analysis was performed using a permutational multivariate analysis of variance (Permanova-Anderson, 2001). The R (R Core Team, 2018) and SigmaPlot 10.0 (Systat Software, 2006) software was used to carry out these analyses.

\section{Results and Discussion}

The results of the analysis of variance and mean test (Table 1) showed that Eucalyptus urocam plants irrigated at 4:30 p.m. or 7:00 p.m. presented higher height, stem diameter, and relative water content; however, without significant increases in total plant weight. The results found for number of leaves, transpiration rate, and total plant weight indicate an interaction between water depths and irrigation times (Table 2).

Table 1. Summary of variance analysis and mean test of Eucalyptus urocam irrigated with water volume of 50\% and $100 \%$ of the retention capacity of the substrate at different hours (7:30 a.m, 11:30 a.m, 4:30 p.m and 7:00 p.m)

\begin{tabular}{|c|c|c|c|c|c|c|c|}
\hline & $\mathrm{DF}$ & $\mathrm{PH}(\mathrm{cm})$ & $\mathrm{SD}(\mathrm{mm})$ & $\mathrm{LN}$ & RWC (\%) & $E\left(\mathrm{~g} \mathrm{H}_{2} \mathrm{O} \mathrm{dia}^{-1}\right)$ & Biom (g) \\
\hline Variation source & & & & & ean squares & & \\
\hline Hour $(\mathrm{H})$ & 3 & $414.74^{\mathrm{ns}}$ & $0.96^{* *}$ & $260.20^{* *}$ & $156.59^{*}$ & $6865.30^{* *}$ & $2.92^{\mathrm{ns}}$ \\
\hline Irrigation (I) & 1 & $2.63^{* *}$ & $1.77^{* *}$ & $4644.00^{*}$ & $68.77^{\mathrm{ns}}$ & $93286.60^{* *}$ & $120.97^{* *}$ \\
\hline $\mathrm{H} \times \mathrm{I}$ & 3 & $11.74^{\mathrm{ns}}$ & $0.11^{\mathrm{ns}}$ & $184.40^{* *}$ & $54.36^{\mathrm{ns}}$ & $2809.20^{* *}$ & $6.45^{*}$ \\
\hline Erro & 32 & 15.04 & 0.11 & 94.90 & 198.61 & 519.31 & 2.11 \\
\hline CV (\%) & & 7.98 & 7.10 & 13.76 & 9.30 & 15.53 & 14.99 \\
\hline Hour & & & & & Means & & \\
\hline 7:30 a.m & & $48.20 \mathrm{a}$ & $4.78 \mathrm{a}$ & $32.00 \mathrm{ab}$ & $77.74 \mathrm{a}$ & $133.90 \mathrm{~b}$ & $8.50 \mathrm{a}$ \\
\hline 11:30 a.m & & $48.80 \mathrm{a}$ & $5.13 \mathrm{a}$ & $38.50 \mathrm{a}$ & $70.98 \mathrm{~b}$ & $133.00 \mathrm{~b}$ & $8.80 \mathrm{a}$ \\
\hline 4:30 p.m & & $48.12 \mathrm{a}$ & $4.41 \mathrm{~b}$ & $26.20 \mathrm{~b}$ & $71.72 b$ & $185.99 \mathrm{a}$ & $8.90 \mathrm{a}$ \\
\hline 7:00 p.m & & $49.20 \mathrm{a}$ & $4.98 \mathrm{a}$ & $34.00 \mathrm{ab}$ & $78.57 \mathrm{a}$ & $133.80 \mathrm{~b}$ & $9.80 \mathrm{a}$ \\
\hline Irrigation & & & & & Means & & \\
\hline $50 \%$ & & $45.36 \mathrm{~b}$ & $4.61 \mathrm{~b}$ & $21.90 \mathrm{~b}$ & $76.06 \mathrm{a}$ & $98.4 b$ & $7.30 \mathrm{~b}$ \\
\hline $100 \%$ & & $51.80 \mathrm{a}$ & $5.03 \mathrm{a}$ & $43.45 \mathrm{a}$ & $73.44 \mathrm{a}$ & $194.8 \mathrm{a}$ & $10.70 \mathrm{a}$ \\
\hline
\end{tabular}

Note. $\mathrm{PH}=$ plant height; $\mathrm{SD}=$ stem diameter; $\mathrm{LN}=$ leaf number; $\mathrm{RWC}=$ relative water content; $\mathrm{E}=$ total transpiration; Biom $=$ total plant biomass. $*$ significant at $5 \%$ and at $* * 1 \%$ probability; ns $=$ not significant according to the $\mathrm{F}$ test. Means followed by the same lower case letter in the column do not differ at $5 \%$ probability according to the Tukey test.

The plant height, stem diameter, number of leaves, transpiration rate, and total plant weight of plants irrigated with $100 \%$ of the retention capacity of the substrate were higher than those of plants under water deficit $13 \%$, $9 \%, 50 \%, 50 \%$, and $32 \%$, respectively. The water deficit resulted in lower availability of water for cell expansion and significant restriction to vegetative growth and corroborate those found by Matos, Freitas, Souza and Lopes, (2018) who identified that the initiation and development of the leaf primordium are dependent on the water status of the plant. The emergence and development of leaf primordia are dependent on the plant's water status.

The reduction of number of leaves recorded in the present study is an important strategy to tolerate water deficit by minimizing transpiration surface, and one of the most efficient forms of delaying dehydration in plants. According to Souza et al. (2015), the reduction in number of leaves, the small variation in relative water content (maintenance of leaf hydration), and the reduction in transpiration rate in Eucalyptus urophylla plants in environments with low water availability denote their tolerance to water deficit.

The reduced transpiration rate, and maintenance of tissue hydration found in plants subjected to water deficit are typical of isohydric plants, which minimize water loss through their high stomatal sensitivity and maintain leaf water potential along the day. However, this small stomatal opening reduces the $\mathrm{CO}_{2}$ influx to carboxylation sites, limiting photosynthesis process and biomass accumulation.

The means of number of leaves and transpiration rate found (Table 2) indicated that plants irrigated at 4:30 p.m. or 7:00 p.m. had intermediate number of leaves and higher transpiration rate. Irrigation at these times probably 
reduced the stomatal sensitivity of the E. urocam plants. When the plants were subjected to water deficit, the greater stomatal opening at these times increased $\mathrm{CO}_{2}$ influx, generating a greater biomass accumulation.

Table 2. Average values of Eucalyptus urocam plants irrigated with water volume referring to $50 \%$ and $100 \%$ of the capacity substrate at different hours (7:30 a.m, 11:30 a.m, 4:30 p.m and 7:00 p.m)

\begin{tabular}{|c|c|c|c|c|c|c|}
\hline \multirow{3}{*}{ Hour } & \multicolumn{6}{|c|}{ Means } \\
\hline & \multicolumn{2}{|c|}{$\mathrm{LN}$} & \multicolumn{2}{|c|}{ Biom (g) } & \multicolumn{2}{|c|}{$E\left(\mathrm{~g} \mathrm{H}_{2} \mathrm{O} \mathrm{dia}^{-1}\right)$} \\
\hline & $50 \%$ & $100 \%$ & $50 \%$ & $100 \%$ & $50 \%$ & $100 \%$ \\
\hline 7:30 a.m. & $15.00 \mathrm{bC}$ & $49.00 \mathrm{aA}$ & $6.63 \mathrm{bA}$ & $10.39 \mathrm{aA}$ & $80.00 \mathrm{bBC}$ & $187.96 \mathrm{aB}$ \\
\hline 11:30 a.m. & $28.40 \mathrm{bA}$ & $48.60 \mathrm{aA}$ & $6.15 \mathrm{bA}$ & $11.63 \mathrm{aA}$ & $70.00 \mathrm{bC}$ & $196.00 \mathrm{aB}$ \\
\hline 4:30 p.m. & $18.80 \mathrm{bBC}$ & $33.60 \mathrm{aB}$ & $8.27 \mathrm{aA}$ & $9.59 \mathrm{aA}$ & $134.00 \mathrm{bA}$ & $273.98 \mathrm{aA}$ \\
\hline 7:00 p.m. & $25.40 \mathrm{bAB}$ & $42.60 \mathrm{aA}$ & $7.97 \mathrm{bA}$ & $11.55 \mathrm{aA}$ & $109.60 \mathrm{bAB}$ & $158.00 \mathrm{aB}$ \\
\hline $\mathrm{CV}(\%)$ & 13.76 & & 15.00 & & 15.53 & \\
\hline
\end{tabular}

Note. $\mathrm{LN}=$ leaf number; Biom = total biomass; $E=$ total transpiration. Means followed by the same lower case letter in the line of each variable at $50 \%$ and $100 \%$ and by capital letter in the column do not differ to a $5 \%$ probability, according to the Tukey test.

The means of the variables evaluated presented low difference when irrigated with $100 \%$ of the water volume; however, plants under water deficit that were irrigated at 4:30 p.m. or 7:00 p.m. (under milder weather conditions) presented higher transpiration rates and total plant weights. According to Tatagiba, Pezzopane, Reis (2015), when eucalyptus plants reach critical levels of leaf water potential, the stomata are partially or almost completely closed.

Table 3. Summary of analysis of variance and mean test of irrigated Eucalyptus urocam plants with water volume of $50 \%$ and $100 \%$ of the retention capacity of the substrate at different hours (7:30 a.m, 11:30 a.m, 4:30 p.m and 7:00 p.m)

\begin{tabular}{|c|c|c|c|c|c|c|}
\hline & $\mathrm{DF}$ & RMR (\%) & SMR (\%) & $\operatorname{LMR}(\%)$ & $\operatorname{SLA}\left(\mathrm{m}^{3} \mathrm{~kg}^{-1}\right)$ & $\mathrm{Chl}(a+b)\left(\mathrm{mg} \mathrm{g}^{-1} \mathrm{MF}\right)$ \\
\hline Variation source & & \multicolumn{5}{|c|}{ Mean squares } \\
\hline Hour $(\mathrm{H})$ & 3 & $82.01^{\mathrm{ns}}$ & $23.67^{* *}$ & $157.59^{* *}$ & $55.30^{* *}$ & $0.36^{* *}$ \\
\hline Irrigation (I) & 1 & $438.31^{* *}$ & $65.53^{* *}$ & $1194.98^{* *}$ & $248.50^{* *}$ & $2.47^{* *}$ \\
\hline $\mathrm{H} \times \mathrm{I}$ & 3 & $37.07^{\mathrm{ns}}$ & $16.08^{* *}$ & $34.31^{* *}$ & $106.91^{* *}$ & $0.63^{* *}$ \\
\hline Erro & 32 & 40.10 & 4.57 & 7.30 & 18.99 & 0.10 \\
\hline $\mathrm{CV}(\%)$ & & 20.98 & 7.44 & 5.00 & 12.50 & 19.5 \\
\hline Hour & & \multicolumn{5}{|c|}{ Means } \\
\hline $7: 30$ a.m & & $30.13 a$ & $26.60 \mathrm{a}$ & $39.67 \mathrm{c}$ & $28.82 \mathrm{a}$ & $1.39 \mathrm{a}$ \\
\hline 11:30 a.m & & $31.62 \mathrm{a}$ & $26.17 \mathrm{a}$ & $42.19 b c$ & $24.18 \mathrm{a}$ & $1.11 \mathrm{a}$ \\
\hline 4:30 p.m & & $26.38 \mathrm{a}$ & $24.55 \mathrm{ab}$ & $49.06 \mathrm{a}$ & $27.60 \mathrm{a}$ & $1.06 \mathrm{a}$ \\
\hline 7:00 p.m & & $33.04 \mathrm{a}$ & $23.26 \mathrm{~b}$ & $43.80 \mathrm{~b}$ & $24.29 \mathrm{a}$ & $1.43 \mathrm{a}$ \\
\hline Irrigation & & \multicolumn{5}{|c|}{ Means } \\
\hline $50 \%$ & & $33.60 \mathrm{~b}$ & $26.42 \mathrm{a}$ & $38.21 b$ & $23.73 b$ & $1.00 \mathrm{~b}$ \\
\hline $100 \%$ & & $26.98 b$ & $23.86 \mathrm{~b}$ & $49.15 \mathrm{a}$ & $28.72 \mathrm{a}$ & $1.50 \mathrm{a}$ \\
\hline
\end{tabular}

Note. $\mathrm{RMR}=$ for root mass ratio; $\mathrm{SMR}=$ stem mass ratio; $\mathrm{LMR}=$ leaf mass ratio, SLA $=$ specific leaf area; $\mathrm{Chl}$ $a+b=$ foliar concentration of total chlorophylls. * significant at $5 \%$ and at $* * 1 \%$ probability; ns $=$ not significant according to the $\mathrm{F}$ test. Means followed by the same lower case letter in the column do not differ at $5 \%$ probability according to the Tukey test.

The irrigation times did not affect root weight ratio (Table 3). The results found for root weight ratio, leaf weight ratio, specific leaf area, and foliar chlorophyll content indicate an interaction between water depths and irrigation times (Table 4). The leaf weight ratio, specific leaf area, and chlorophyll content of plants irrigated with $100 \%$ of the retention capacity of the substrate were respectively $23 \%, 18 \%$, and $34 \%$ higher than those of plants under 
water deficit. The root weight ratio and stem weight ratio of plants under water deficit were respectively $20 \%$ and $10 \%$ higher than those of plants irrigated with $100 \%$ of the water volume.

According to Wegner (2017), the first biophysical effect of water stress is a decrease in cellular volume, affecting mainly the elongation of roots. Under these conditions, the $E$. urocam plants allocate assimilates to increase root growth (root weight ratio) and hydraulic conductivity (stem weight ratio) to the detriment of leaf weight ratio and chlorophyll pigments $(\mathrm{Chl} a+\mathrm{Chl} b)$. Moreover, E. urocam plants under water deficit had reduced specific leaf area, probably due to their increased leaf thickness - increases in cuticle to minimize transpiration and maintain hydrated tissues.

Plants irrigated at 4:30 p.m. or 7:00 p.m. presented higher leaf weight ratio, specific leaf area, and chlorophyll ( $a$ and $b$ ) contents, and lower stem weight ratio under water deficit (Table 4). Despite the small difference between the means of the variables in the treatments irrigated with $100 \%$, plants irrigated at 4:30 p.m. or 7:00 p.m. were less acclimated to the water deficit with minor morphophysiological changes. In addition, the higher specific leaf area found indicates a lower leaf thickness and, therefore, lower protection from tissue dehydration.

Table 4. Interaction average test of irrigated Eucalyptus urocam plants with water volume of $50 \%$ and $100 \%$ of the retention capacity of the substrate at different hours (7:30 a.m, 11:30 a.m, 4:30 p.m and 7:00 p.m)

\begin{tabular}{|c|c|c|c|c|c|c|c|c|}
\hline \multirow{3}{*}{ Hour } & \multicolumn{8}{|c|}{ Means } \\
\hline & \multicolumn{2}{|c|}{$\mathrm{Chl} a+b\left(\mathrm{mg} \mathrm{g}^{-1} \mathrm{MF}\right)$} & \multicolumn{2}{|c|}{ SMR (\%) } & \multicolumn{2}{|c|}{$\operatorname{LMR}(\%)$} & \multicolumn{2}{|c|}{$\operatorname{SLA}\left(\mathrm{m}^{2} \mathrm{~kg}^{-1}\right)$} \\
\hline & $50 \%$ & $100 \%$ & $50 \%$ & $100 \%$ & $50 \%$ & $100 \%$ & $50 \%$ & $100 \%$ \\
\hline $7: 30$ a.m & $0.97 \mathrm{bA}$ & $1.81 \mathrm{aAB}$ & $28.25 \mathrm{aA}$ & $24.96 \mathrm{bA}$ & $33.85 \mathrm{bB}$ & $45.49 \mathrm{aB}$ & $24.56 \mathrm{bA}$ & $33.10 \mathrm{aA}$ \\
\hline 11:30 a.m & $0.82 \mathrm{bA}$ & $1.41 \mathrm{aB}$ & $28.29 \mathrm{aA}$ & $24.07 \mathrm{bAB}$ & $35.35 \mathrm{bB}$ & $49.04 \mathrm{aAB}$ & $18.01 \mathrm{bB}$ & $30.36 \mathrm{aAB}$ \\
\hline 4:30 p.m & $1.18 \mathrm{aA}$ & $0.94 \mathrm{aC}$ & $23.95 \mathrm{aB}$ & $25.15 \mathrm{aA}$ & $46.30 \mathrm{bA}$ & $51.82 \mathrm{aA}$ & $28.31 \mathrm{aA}$ & $26.91 \mathrm{aBC}$ \\
\hline 7:00 p.m & $1.03 \mathrm{bA}$ & $1.84 \mathrm{aA}$ & $25.22 \mathrm{aAB}$ & $21.30 \mathrm{bB}$ & $37.36 \mathrm{bB}$ & $50.24 \mathrm{aA}$ & $28.31 \mathrm{aA}$ & $24.51 \mathrm{aC}$ \\
\hline $\mathrm{CV}(\%)$ & 19.50 & & 7.44 & & 5.00 & & 12.50 & \\
\hline
\end{tabular}

Note. Chl $a+b=$ foliar concentration of total chlorophylls; SMR $=$ stem mass ratio; LMR = leaf mass ratio; SLA $=$ specific leaf area. Averages followed by the same lowercase letter in the rows and upper case in the columns do not differ from each other by the Tukey test at $5 \%$ probability.

The multiple regression model used to evaluate the effects of the variables on the total plant weight of E. urocam plants (Table 5) showed that the stem diameter, stem weight ratio, transpiration rate, and total chlorophylls explained $77 \%$ of the variance of the total plant weight of the E. urocam plants.

Table 5. Multiple regression model to evaluate the effect of variables on the biomass of irrigated Eucalyptus urocam plants with water volume referring to $50 \%$ and $100 \%$ of the retention capacity of the substrate at different hours (7:30 a.m, 11:30 a.m, 4:30 p.m and 7:00 p.m)

\begin{tabular}{lllllll}
\hline Biomas $(\mathrm{g})$ & $\mathrm{R}^{2}=0.77$ & $\mathrm{~F}(6.33)=18.667$ & $\mathrm{p}<0.0001$ & & & \\
\hline & Beta & Std. Err. of Beta & $\mathrm{B}$ & Std. Err. of B & $\mathrm{t}(19)$ & $\mathrm{p}$-level \\
\hline Intercept & & & 6.826 & 3.963 & 1.72 & 0.09 \\
SD & 0.275 & 0.115 & 1.23 & 0.56 & 2.38 & $0.02^{* *}$ \\
SMR & -0.234 & -0.195 & -0.195 & 0.086 & -2.26 & $0.03^{* *}$ \\
$E$ & 0.337 & 0.115 & 0.013 & 0.004 & 2.91 & $0.006^{*}$ \\
Chl $(a+b)$ & 0.384 & 0.133 & 2.035 & 0.705 & 2.88 & $0.006^{*}$ \\
\hline
\end{tabular}

Note. ** Significant at 5\%; * Significant at $1 \%$; Explanation of the $\mathrm{R}^{2}$ model $=0.77 ; \mathrm{SD}=$ Stem diameter; SMR $=$ stem mass ratio; $E=$ Transpiration; $\mathrm{Chl}(a+b)=$ Total Chlorophyll.

The stem diameter, stem weight ratio, transpiration rate, and chlorophyll contents were the most determinant variables for biomass production. Plants irrigated at 4:30 p.m. or 7:00 p.m. had a greater biomass accumulation and less sensitivity to water stress than those in the other irrigation times. 
The principal component analysis (PCA) (Figure 1) explained $79.8 \%$ of the data variance, and formed two groups: the first for the right of axis 1 , with plants irrigated with water depths corresponding to $50 \%$, and the second for the left of axis 1 , with plants irrigated with $100 \%$ of the retention capacity of the substrate.

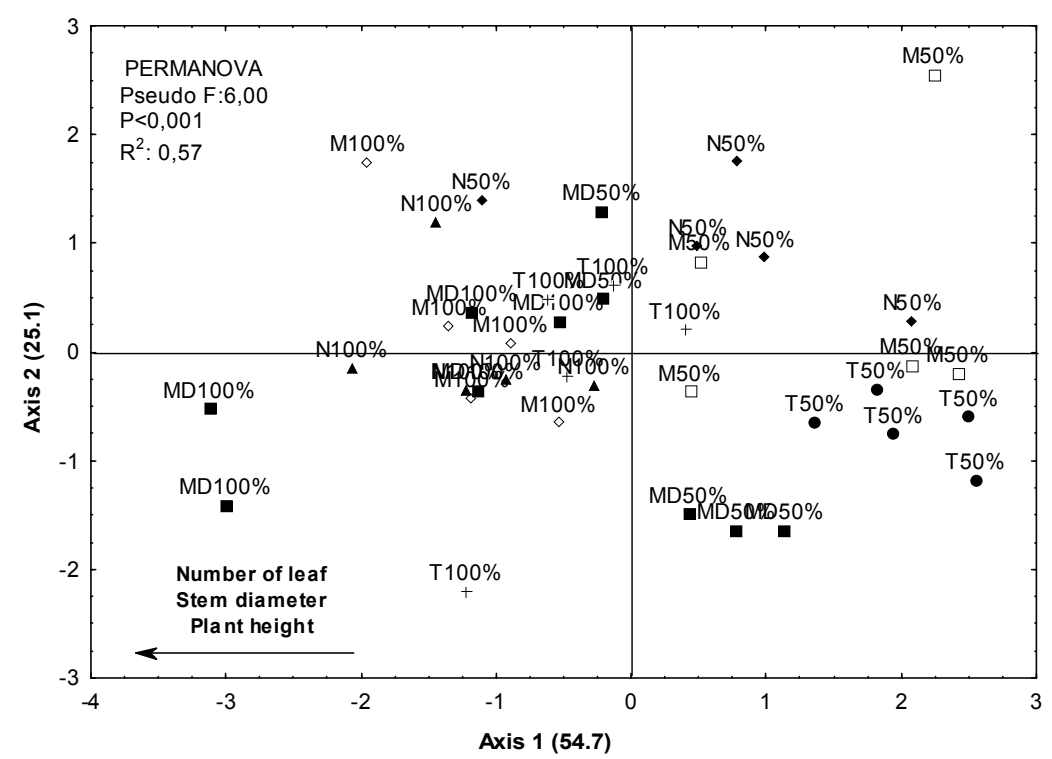

Figure 1. Principal components analysis for all variables studied in Eucalyptus urocam plants irrigated with water volumes referring to $50 \%$ and $100 \%$ of the retention capacity of the substrate at different times $(\mathrm{M}=7: 30$ a.m., $\mathrm{MD}=11: 30$ a.m., $\mathrm{T}=16: 30$ p.m. and $\mathrm{N}=19: 00$ p.m.)

This indicates that the difference in water supply was sufficient to alter the growth of $E$. urocam plants, which, in general, have an isohydric mechanism to maintain tissue hydration, minimizing transpiration by reducing stomatal opening (Matos et al., 2016).

The similarity in total plant weight between treatments irrigated with water depths corresponding to $100 \%$ of the retention capacity of the substrate was due to the reduced time of the experiment. However, the marked changes in specific leaf area, transpiration rate, stem weight ratio, and chlorophyll $(a+b)$ contents indicated that the plants irrigated at 4:30 p.m. or 7:00 p.m. had less stomatal sensitivity and fewer signs of protection from water deficit. Therefore, they have higher growth potential, by allowing greater $\mathrm{CO}_{2}$ influx and, consequently, significant increases in the photosynthesis, and biomass accumulation.

Irrigations at 7:30 a.m. or 11:30 a.m. caused significant water losses by evaporation because of the high air temperature and low air relative humidity during the day. Irrigations at these times compromise the water inflow to the soil-plant-atmosphere system due to the reduced plant stomatal opening. In these conditions, plants have lower water availability at the end of the afternoon and at night. Contrastingly, irrigations at 4:30 p.m. or 7:00 p.m. resulted in lower losses by direct water evaporation, the plants remain hydrated and with opened stomata until at least the following morning due to low transpiration and evaporation at night times. According to Kerbauy et al. (2013), maintenance of tissue turgidity at night is essential for growth.

\section{Conclusions}

Eucalyptus urocam plants subjected to water deficit presented high stomatal sensitivity, reduced transpiration rate, and maintained hydration, which are characteristics of isohydric plants. However, E. urocam plants irrigated at 4:30 p.m. or 7:00 p.m. presented lower stomatal sensitivity and higher biomass accumulation potential; therefore, irrigations between 4:30 p.m. and 7:00 p.m. are recommended for Eucalyptus urocam plants at their initial growth stage.

\section{References}

Acuña, E., Rubilar, R., Cancino, J., Albaugh, T. J., \& Maier, C. A. (2018). Economic assessment of Eucalyptus globulus short rotation energy crops under contrasting silvicultural intensities on marginal agricultural land. Land Use Police, 76, 329-337. https://doi.org/10.1016/j.landusepol.2018.05.028 
Alvares, C. A., Stape, J. L., Sentelhas, P. C., Gonçalves, J. L. M., \& Sparovek, G. (2013). Köppen's climate classification map for Brazil. Meteorologische Zeitschrift, 22(6), 711-728. https://doi.org/10.1127/09412948/2013/0507

Anderson, M. J. (2001). A new method for non-parametric multivariate analysis of variance. Austral Ecology, 26, 32-46. https://doi.org/10.1111/j.1442-9993.2001.01070.pp.x

Binkley, D., Campoe, O. C., Alvares, C., Carneiro, R. L., Cegatta, Í., \& Stape, J. L. (2017). The interactions of climate, spacing and genetics on clonal Eucalyptus plantations across Brazil and Uruguay. Forest Ecology and Management, 405, 271-283. https://doi.org/10.1016/j.foreco.2017.09.050

Cabral, O. M. R., Rocha, H. R., Gash, J. H. C., Ligo, M. A. V., Freitas, H. C., \& Tatsch J. D. (2010). The energy and water balance of a Eucalyptus plantation in southeast Brazil. Journal of Hydrology, 388, 208-216. https://doi.org/10.1016/j.jhydrol.2010.04.041

Dos Anjos, R. A. R., Santos, L. C. S., Oliveira, D. B., Amaro, C. L., Rios, J. M., Rocha, G. T., \& Matos, F. S. (2017). Initial growth of Jatropha curcas plants subjected to drought stress and silicon (Si) fertilization. Australian Journal of Crop Science, 11(4), 479-484. https://doi.org/10.21475/ajcs.17.11.04.377

Git Forestry Consulting. (2008). Eucalyptus Global Map 2008: Cultivated forests worldwide. Retrieved from http://git-forestry-blog.blogspot.com/2008/09/eucalyptus-global-map-2008- cultivated.html

Jesus, M. S., Costa, L. J., Ferreira, J. C., Freitas, F. P., Santos, L. C., \& Rocha, M. F. V. (2017). Caracterização energética de diferentes espécies de eucalyptus. Floresta, 47(1), 11-16. https://doi.org/10.5380/rf.v47i1. 48418

Kerbauy, G, B. (2013). Fisiologia Vegetal (2nd ed.). Rio de Janeiro, Guanabara Koogan.

Lopes, V. A., Souza, B. R., Moura, D. R., Silva, D. Z., Silveira, P. S., \& Matos, F. S. (2015). Initial growth of eucalyptus plants treated with gibberellin. African Journal of Agricultural Research, 10(11), 1251-1255.

Matos, F. S., Freitas, I. A. S., De Souza, B. R., \& Lopes, V. A. (2018). Crescimento de plantas de Tectona grandis sob restrição hídrica. Agrarian, 11(39), 14-21. https://doi.org/10.30612/agrarian.v11i39.5284

Matos, F. S., Oliveira, P. R. C., Gil, J. L. R. A., De Sousa, P. V., Gonçalves, G. A., Sousa, M. P. B. L., Da Silveira, P. S., \& Da Silva, L. M. (2016). Eucalyptus urocam drought tolerance mechanisms, African Journal of Agricultural, 11(18), 1617-1622. https://doi.org/10.5897/AJAR2016.10918

Payn, T., Carnus, J. M., Freer-Smith, P., Kimberley, M., Kollert, W., Liu, S., ... Wingfield, M. J. (2015). Changes in planted forests and future global implications. Forest Ecology and Management, 352, 57-67. https://doi.org/10.1016/j.foreco.2015.06.021

Power E. (2017). The goodman of Paris (Le Ménagier de Paris), a treatise on moral and domestic economy by a citizen of Paris. Harcourt, Brace, \& Co., New York, 1928. In W. R. Adams, \& K. T. Zeleke (2017). Diurnal effects on the efficiency of drip irrigation. Irrigation Science, 35(2), 141-157.

Pozo, P., \& Säumel, I. (2018). How to bloom the green desert: Eucalyptus plantations and native forests in uruguay beyond black and white perspectives. Forests, 9(10), 1-16. https://doi.org/10.3390/f9100614

R Core Team. (2018). R: A language and environmental for statistical computing. Vienna, Austria. Retrieved from http://www.R-project.org

Sá, F. V. S., Mesquita, E. F., Souza, F. M., Mesquita, S. O., Paiva, E. P., \& Silva, A. M. (2017). Depleção de água e composição do substrato na produção de mudas de melancia. Revista Brasileira de Agricultura Irrigada, 11(3), 1398-1406. https://doi.org/10.7127/rbai.v11n300550

Schlaepfer, D. R., Bradford, J. B., Lauenroth, W. K., Munson, S. M., Tietjen, B., Hall, S. A., ... Jamiyansharav, K. (2017). Climate change reduces extent of temperate drylands and intensifies drought in deep soils. Nature Communications, 8(14196), 1-9. https://doi.org/10.1038/ncomms14196

Sette Junior, C. R., Tomazello Filho, M., Lousada, J. L. P. C., \& Laclau, J. P. (2010). Crescimento em diâmetro do tronco das árvores de Eucalyptus grandis e relação com as variáveis climáticas e fertilização mineral. Revista Árvore, 34(6), 979-990. https://doi.org/10.1590/S0100-67622010000600003

Sokal, R. R., \& Rolf, F. J. (1995). Biometry (3rd ed.). New York, USA.

Souza, B. R., Freitas, I. A. S., Lopes, V. A., Rosa, V. R., \& Matos, F. S. (2015). Growth of eucalyptus plants irrigated with saline water. African Journal of Agricultural, 10(10), 191-196. https://doi.org/10.5897/ AJAR2014.9087 
Systat Software. (2006). SigmaPlot for windows (Version 10.0). San Jose: Systat Software.

Tatagiba, S. D., Pezzopane, J. E. M., Dos Reis, E. F., \& Penchel, R. M. (2009). Desempenho de clones de eucalipto em resposta a disponibilidade de água no substrato. Revista Engenharia na Agricultura-Reveng, 17(3), 179-189. https://doi.org/10.13083/reveng.v17i3.134

Tatagiba, S. D., Pezzopane, J. E. M., \& Reis, E. F. (2015). Fotossíntese em Eucalyptus sob diferentes condições edafoclimáticas. Revista Engenharia na Agricultura-Reveng, 23(4), 336-345. https://doi.org/10.13083/ reveng.v23i4.573

Valdés, A. E., Irar S., Majada, J. P., Rodríguez, A., Fernández, B., \& Pagès, M. (2013). Drought tolerance acquisition in Eucalyptus globulus (Labill.): A research on plant morphology, physiology and proteomics. Journal of Proteomics, 79, 263-276. https://doi.org/10.1016/j.jprot.2012.12.019

Wegner, L. H. (2017). A pump/leak model of growth: the biophysics of cell elongation in higher plants revisited. Functional Plant Biology, 44(2), 185-197. https://doi.org/10.1071/FP16184

Wellburn, A. R. (1994). The spectral determination of chlorophylls a and b, as well as total carotenoids, using various solvents with spectrophotometers of different resolution. Journal of Plant Physiology, 144(3), 307-313. https://doi.org/10.1016/S0176-1617(11)81192-2

\section{Copyrights}

Copyright for this article is retained by the author(s), with first publication rights granted to the journal.

This is an open-access article distributed under the terms and conditions of the Creative Commons Attribution license (http://creativecommons.org/licenses/by/4.0/). 